\title{
Children's rights jurisprudence in South Africa - a 20 year retrospective
}

\section{Julia Sloth-Nielsen}

$B A L L D$

Professor, Dept of Public Law and Jurisprudence, University of the Western Cape and Professor of Children's Rights in the Developing World, Leiden University

\begin{abstract}
SUMMARY
This article provides a 20 year overview of children's rights jurisprudence in South Africa, with a predominant focus on cases in the public law arena (as opposed to family law). After identifying various themes that the author believes are worthy of note, such as the interplay between best interests and the child's rights to dignity; the innovative remedies that have characterised child rights case outcomes; and the courts' engagement with international law, the article concludes that constitutionalising children's rights has the advantage of elevating their status to the highest point in a legal system. Moreover, rights having the capacity to shift the balance of power, and for children, the framing of their rights in constitutional terms has resoundingly dislodged paternalistic approaches rooted in welfarism.
\end{abstract}

\section{Introduction}

This retrospective builds on a number of previous endeavours to give life to the significant jurisprudence that has developed in 20 years of children's rights litigation in South Africa. This article will provide a synopsis of previous efforts to unpack the overarching contribution of children's rights litigation over somewhat more than two decades, with a few brief updates of more recent cases. Thereafter, the article will engage with specific themes that emerge from the case law. A summative assessment of the contribution of children's rights litigation to the constitutional project of embedding children's right ideals in practice forms the conclusion.

\section{Overview of previous endeavours}

Articles in 2002, 2008 and 2013 appear to have laid a basis for the systemic consideration of South African children's rights jurisprudence in aggregate. The 2002 publication ${ }^{1}$ was undertaken in an effort to explore whether the generous predictions of an earlier article on the supposed impact that the constitutionalisation of children rights was going to have, had in fact born fruit. The findings of that analysis were that the initial

1 Sloth-Nielsen "Children's rights in the South African courts: An overview since ratification of the UN Convention on the Rights of the Child" 2002 IJCR 137.

How to cite: Sloth-Nielsen 'Children's rights jurisprudence in South Africa - a 20 year retrospective' 
constitutional promise had not been met. It was asserted that children's constitutional rights had largely been harnessed by adults in pursuit of their own claims, and that children's individual interests had not taken centre stage. Children had been all but invisible in constitutional litigation at that point, prompting Justice Albie Sachs in an oft quoted postscript to lament that that the Constitutional Court (hereafter CC) was not even appraised of the views of the scholars whose parents were seeking a confirmation of their parental rights to permit the practice of corporal punishment in private schools. ${ }^{2}$ This period also saw the disappointing outcome for children's rights advocacy heralded by the then major socioeconomic rights case, Government of the Republic of South Africa and others $v$ Grootboom and others. ${ }^{3}$ The CC declined to interpret the child's rights to basic nutrition, shelter, basic health care and social services in section 28(1)(c) of the Constitution to encompass a directly enforceable claim for a minimum level of shelter against the state for destitute children, unless such children were orphaned, abandoned or otherwise lacked a family environment. The decision thereby evidently closed the door to a more expansive reading which would see children have a preferential claim to resources, as some academics had suggested was the true meaning of section 28(1)(c). ${ }^{4}$

The 2008 article, published in the same journal, was geared towards an international audience potentially following the desirability of justiciable and constitutionally enshrined legal rights for children as an avenue for the enhanced domestication of the United Nations Convention on the Rights of the Child (CRC). ${ }^{5}$ This article ${ }^{6}$ adopted the framework of the four cardinal pillars of the CRC - non-discrimination, best interests, the right to life, survival and development, and freedom to express views and have those views taken into account - and attempted to classify an increasing array of case law concerning children's rights into one of those headings. The article indicated that the pendulum had indeed swung towards an identification of children's interests eo nomine.

2 Christian Education South Africa v Minister of Education 200010 BCLR 1051 (CC).

3200011 BCLR 1169 (CC).

4 Creamer "The implication of socio-economic rights jurisprudence for government planning and budgeting: the case of children's socio-economic rights" 2004 Law, Democracy and Development 221.

5 UNICEF Innocenti Centre "Law reform and the implementation of Convention on the Rights of the Child" 2008 available at https://www.unicef -irc.org/publications/493-law-reform-and-the-implementation-of-the-conven tion-on-the-rights-of-the-child.html; see for examples of the international interest in the South African experience of constitutionalising children's rights, Tobin "Increasingly seen and heard: the constitutional recognition of children's rights" 2005 SAJHR 86 and O'Mahony "The promises and pitfalls of constitutionalising children's rights" 2019 Human Rights Law Review (in press).

6 Sloth-Nielsen and Mezmur " $2+2=5$ ? Exploring the Domestication of the CRC in South African Jurisprudence (2002-2006)" 2008 IJCR 1. 
Cited examples of cases during that era illustrating this point were Centre for Child Law $v$ Minister for Home Affairs ${ }^{7}$ (concerning the interests of migrant children in detention), $A D v D W^{8}$ (whether "nude" guardianship orders could be granted to subvert the intercountry adoption process), De Reuck $v D P P^{9}$ (upholding the ban on possession of child pornography in children's best interests), and Brandt $v S^{10}$ (juvenile sentencing and the restrictive use of deprivation of liberty). The conclusions were reached that children's interests had featured prominently in litigation during that period, with their views being taken into account, legal representation for them being raised by judges mero motu, and curators appointed to oversee their interests in legal proceedings. Furthermore a notable increase in public interest litigation had surfaced, in cases such as $K h o s a^{11}$ (forcing the payment of social grants to children of permanent residents) and Treatment Action Campaign ${ }^{12}$ (declaring the limitations on the public health sites at which the anti retroviral drugs would be available to mothers giving birth unconstitutional). Children's rights had been employed both as a sword (including an order compelling the provision of adequate sleeping facilities for children in alternative care in the so called Luckhoff case brought by the Centre for Child Law on behalf of the school with that name, ${ }^{13}$ for instance) and as a shield (for example, in De Reuck to resist a claim that the offender's right to privacy and freedom of expression were violated via the legislative ban relating to child pornography). Further, customary law had been shaken to the core in the Bhe case, ${ }^{14}$ which overruled the foundational system of male primogeniture in inheritance. The reasons advanced at the time for the upswell in children's litigation remain valid: we averred that "substantial credit must go to public interest litigators, such as the Womens' Legal Centre (who took the Bhe case to the CC), and the Centre for Child Law, established during the period covered by that review, for bringing children's interests to the fore in judicial proceedings." ${ }^{15}$ We suggested that there was no reason to believe that the impact of public interest litigation in this sphere was going to decline or dissipate and hence, that "the further development of a coherent and rights-based child jurisprudence seems promising." 16 As the title of the article suggested, it was argued that the impact of children's rights litigation in constitutional jurisprudence was already, by then, more than the sum of its parts.

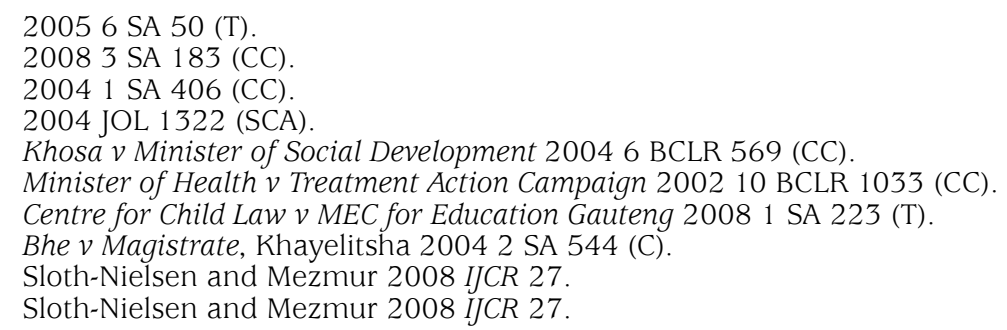


In 2013, a follow up was penned by myself and Helen Kruuse. ${ }^{17}$ The article highlighted eight areas of distinction in this five-year period. These included: judicial approval of resource mobilisation for the fulfilment of children's rights, ${ }^{18}$ emphasis on the quality of and standards in education; ${ }^{19}$ the development of innovative remedies to deal with unreasonable state measures affecting children; ${ }^{20}$ and an increasing focus on the right to dignity of the child. ${ }^{21}$

The authors concluded that the scope of the cases cited pointed to the growing insertion of children's rights considerations in increasingly diverse areas of legal interaction. Furthermore, the authors posited that the CRC and ACRWC - together with non-binding sources of international law - had substantively informed and enriched the jurisprudence of South African courts, such that it was claimed that South Africa may have crossed an invisible line from being a dualist to a monist state regarding the incorporation of international law in so far as children's rights were concerned. Finally, it was suggested that South African courts had begun to construct an image of the "constitutional child". It was asserted that a starting point must be the now famous dictum of Sachs J in $S \mathcal{V} M:^{22}$

"Every child has his or her own dignity. If a child is to be constitutionally imagined as an individual with a distinctive personality, and not merely as a miniature adult waiting to reach full size, he or she cannot be treated as a mere extension of his or her parents, umbilically destined to sink or swim with them". 23

Elaborating this vision, Justice Sachs continued in a less often quoted vein:

"Individually and collectively all children have the right to express themselves as independent social beings, to have their own laughter as well as sorrow, to play, imagine and explore in their own way, to themselves get to understand their bodies, minds and emotions, and above all to learn as they grow how they should conduct themselves and make choices in the wide social and moral world of adulthood. And foundational to the enjoyment of the right to

17 Sloth-Nielsen and Kruuse "A maturing manifesto: The Constitutionalisation of Children's Rights in South African Jurisprudence 2007-2012” 2013 IJCR 646.

18 NAWONGO v MEC of Social Development, Free State 2010 ZAFSHC 73; 2011 ZAFSHC 84; Western Cape Forum for Intellectual Disability $v$ Government of the Republic of South Africa 20115 SA 87 (WCC).

19 Governing Body of the Juma Musjid Primary School $v$ Essay 20118 BCLR 761 (CC); Centre for Child Law v Minister of Basic Education 2012 ZAECGHC 60; Section 27 v Minister of Education 2012 ZAGPPHC 114.

20 DPP, Transvaal v Minister of Justice and Constitutional Development 20092 SACR 77 (CC); Jonker $v$ The Manager, Gali Thembani/JJ Serfontein School 2012 ZAECGHC 12 .

21 S v M (Centre for Child Law as Amicus Curiae) 20083 SA 232 (CC). See too C $v$ Department of Health and Social Development, Gauteng 2012 ZACC 1 and M $v$ Johncom Media Ltd; 20094 SA 7 (CC).

$22 S$ v M (Centre for Child Law as Amicus Curiae) supra.

23 Para 18. 
childhood is the promotion of the rights as far as possible to live in a secure and nurturing environment free from violence, fear, want and avoidable trauma." 24

The picture of constitutional childhood, the authors said had been painted, was one of protection coupled with emancipation, of freedom to explore, blended with adult guidance and compass. ${ }^{25}$

\section{Other significant more recent overviews}

Skelton's new chapter in Child Law in South Africa ${ }^{26}$ provides a comprehensive analysis of the constitutional protection of children's human rights. She explains at length the role of amici curiae in children's rights litigation, citing a string of cases, especially post 2008, in which the amicus briefs played a substantial role. ${ }^{27}$ She illustrates the nascent but significant dynamic of children's direct involvement in litigation, citing amongst others Centre for Child Law v Hoërskool Fochville ${ }^{28}$ in which a group of children were represented collectively by the Centre, and had their expressed views and interests taken into account by way of questionnaires that they had completed. Two noteworthy (and child rights compliant) features of the skirmish included that the right to represent the children's views was accepted in the face of a claim that their interests could be perfectly adequately put forward by their parents, since these had been cited as respondents in the case; and that the children's privacy and anonymity would be preserved through denying the applicants direct access to the individual questionnaires.

Skelton's chapter expounds on the array of remedies that have been fashioned in constitutional litigation concerning children, including orders of invalidity resulting in severance of offending provisions, orders of invalidity resulting in a "reading in", orders of invalidity resulting in the requirement of amending legislation, ${ }^{29}$ structural interdicts or supervisory orders, and damages awards, such as in $M R v$ Minister of safety and Security ${ }^{30}$ where the child successfully sued for wrongful arrest and detention. ${ }^{31}$

Understandably, and somewhat concealed in the analysis, are the gains for children's rights brought about by settlements and agreements:

24 Para 19

25 Sloth-Nielsen and Kruuse 2013 IJCR 671.

26 Skelton "Chapter 11: Constitutional protection of Children's Rights" in Boezaart T (ed) Child Law in South Africa 2017.

27 Skelton “Chapter 11: Constitutional protection of Children's Rights” 334.

2820162 SA 121 (SCA).

29 Notably after Teddy Bear Clinic $v$ Minister of Justice and Constitutional Development 20142 SA 208 (CC) which lead to the promulgation of the Criminal Law (Sexual Offences) Amendment Act 5 of 2015.

3020162 SACR 540 (CC).

31 See further Jephson and Mngomezulu "Constitutional Litigation Procedure" in J Brickhill (ed) Public Interest Litigation in South Africa Juta 2018147 et seq. 
a recent example concerns the settlement between the Centre and the MEC for Social Development, Gauteng, MEC for Health Gauteng and MEC for Education, Gauteng ${ }^{32}$ relating to the absence of any services for children with severe or profound disruptive behaviour disorders who come into conflict with the law. This settlement saw the Departments agreeing to the development of a properly costed and budgeted intersectoral policy and implementation plan to ensure, amongst others, that appropriate prevention and early intervention plans are implemented to cater for children at risk of developing severe or profound disruptive behaviour disorders, within their families and communities as far as possible; and that an appropriate spread of residential programmes and mental health care services specifically geared towards catering for children with severe or profound disruptive behaviour disorders be developed and provided.

Not unexpectedly, Skelton reflects on the key relationship between s 28(2) enshrining the paramountcy of the best interests of the child principle, and other constitutional rights. As a self-standing right and a guiding principle, ${ }^{33}$ it has been drawn into a variety of cases she cites concerning the right to parental or family care, international child abduction, child pornography, the right to housing, adoption, customary inheritance law, health care, the right to social assistance, child's right to privacy and dignity, the testimony of child victims and witnesses, the right of children removed from their families to have that removal reviewed by a court, the right of children not to be prosecuted for consensual sexual activity, the right of child sex offenders not to be automatically placed on the sex offenders register, and the rights of children in conflict with the law not to be detained except as a measure of last resort. 34

She concludes that the case law referred to "demonstrates a real commitment by the courts towards interpreting and applying these paper rights to the real-life situation of children. The approach to children in litigation encompasses both the need to protect children and advance their [autonomy] rights.",35

An even more upbeat assessment is provided by her in the recent publication on "Public Interest litigation in South Africa". ${ }^{36}$ Using as a leitmotif the food metaphor inherent in the claim that children's rights

32 Case 77362/16 Gauteng Provincial Division Pretoria.

33 Although, as courts have pointed out, this does not mean that s 28(2) is not itself capable of limitation: see for a fuller discussion $S v M$ (Centre for Child Law as Amicus Curiae) par 25 and 26 and Centre for Child Law v Minister of Justice and Constitutional Development 20092 SA SACR 477 (CC).

34 Skelton "Chapter 11: Constitutional protection of Children's Rights" 346- 347 .

35 Skelton supra 358.

36 Skelton "Children's Rights" in J Brickhill (ed) Public Interest Litigation in South Africa Juta 2018 at 258. 
were "chicken soup", 37 she asserts that "the South African courts' treatment of children's rights has been far more piquant than the bland potage that was apparently expected".38

In this chapter, she engages in a cook's tour of significant cases in more or less chronological order, starting with Williams ${ }^{39}$ in the interregnum during which the interim constitution held force, and proceeding to the landmark judgment in $T A C^{40}$ in 2002, before describing the effervescence of children's rights litigation that began to occur around 2007. She accords a prominent space to $S \mathcal{V} M$, and its elegant rendition of the "constitutionally imagined child". This case she describes as the "post constitutional locus classicus on the best interests principle". 41

In the criminal law sphere, she contends that the courts have been unwavering in their recognition that children are different from adults, and that their culpability is affected by their lack of maturity. ${ }^{42}$ She avers that the CC has not failed to grasp the nettle in the context of difficult cases involving sexual offences and the overreach of legislation. ${ }^{43}$ The chapter reviews the then state of progress of litigation around the constitutionality of the common law rule permitting parents to reasonably chastise their children in $Y G \vee S,{ }^{44}$ in which a CC ruling is awaited.

In conclusion, the chapter alludes to the overall disappointing results in expounding children's access to socio-economic rights, though the concessions as regards the duties of the state to fulfil these when children are without parental care or are removed from the family environment are acknowledged. ${ }^{45}$ It predicts future litigation in the area of migrant children's rights, as well as relating to birth registration and stateless children. Tellingly, the chapter speaks to the high level of strategic and deliberate intention behind the children's litigation of the last decade, including in relation to cases that were brought to court, as well as to those that were not.

37 Sloth-Nielsen "Chicken Soup or Chain Saws: Some implications of the constitutionalisation of children's rights in South Africa" 1996 Acta Juridica 6, based on a throwaway remark made by erstwhile opposition leader Tony Leon at the time that children's rights were debated in the Constitutional Assembly.

38 Skelton "Children's Rights” 258.

$39 S v$ Williams 19953 SA 632 (CC) in which juvenile whipping as a sentence was ruled unconstitutional.

40 Minister of Health $v$ Treatment Action Campaign 20026 SA 121 (CC).

41 Skelton "Children's Rights" 269.

42 Skelton “Children's Rights” 271.

43 Teddy Bear Clinic v Minister of Justice and Constitutional Development, supra, and J V National Director of Public Prosecutions and Another 2014 (2) SACR 1 (CC).

4420181 SACR $64(\mathrm{GJ})$.

45 Centre for Child Law v MEC for Education, Gauteng 20081 SA 223 (T). 


\section{The education terrain}

The education terrain presents an obvious site for contestation about children's rights. In previous work, reference was made to Juma Musjid ${ }^{46}$ (confirming that the right to education is immediately enforceable and not subject to progressive realisation) and Western Cape Forum for Intellectual Disability, ${ }^{47}$ but a veritable flood of litigation has been brought since then to attempt to raise education standards and to improve service delivery. This frontier has been attacked by Equal Education, Section 27, Lawyers for Human Rights, the Centre for Child Law, and the Legal Resources Centre. ${ }^{48}$ The well known "mud schools" cases represented the first real foray in the endeavour to compel the Eastern Cape provincial government to provide facilities conducive to teaching and learning and resulted in a settlement with government committing to addressing the infrastructure backlog. ${ }^{49}$ As Kamga notes, the "courts have been unambiguous in holding that education cannot be considered available if learners are not provided with textbooks". 50 The Supreme Court of Appeal has confirmed that the Constitution entitles every learner at a public school to be provided with a textbook prescribed for his or her grade before commencement of teaching for the course for which that textbook is prescribed. ${ }^{51}$ The duty to fulfil this right rests on the State.

Madzodzo $v$ Minister of Basic Education ${ }^{52}$ dealt with desks and chairs for reading and writing, also as part of the immediately realisable right to basic education; post provisioning for both teaching and non-teaching staff was the subject matter of Centre for Child Law $v$ Minister for Basic Education; ${ }^{53}$ physical accessibility of schools through the provision of free transport where learners could not otherwise access their schools has been addressed; ${ }^{54}$ and in the Linkside cases discussed by Kamga, ${ }^{55}$ the court ordered that the affected schools be refunded for teacher costs they had had to bear themselves, and that the educators concerned be properly appointed. According to Kamga, this was South Africa's first

46 Governing Body of the Juma Musjid Primary School v Essay 2011 (8) BCLR 761 (CC). This was the first time that the Constitutional Court directly considered the content of the right to education.

47 Western Cape Forum for Intellectual Disability $v$ Government of the Republic of South Africa 20115 SA 87 (WCC).

48 See MacConachie and Breener "Litigating the Right to Basic Education" in J Brickhill (ed) Public Interest Litigation in South Africa Juta 2018.

49 Kamga "The right to a basic education" in Boezaart (ed) Child Law in South Africa 526.

50 Kamga "The right to a basic education" 527.

51 Section $27 v$ Minister for Education 20164 SA 63 (SCA).

5220143 SA 441 (ECM).

5320133 SA 183 (ECG)

54 See the cases discussed by Kamga "The right to a basic education" 531532 .

55 Linkside $v$ Minister of Basic Education 2014 ZAECGHC 111; Linkside $v$ Minister of Basic Education 2015 ZAECGHC 36; Kamga "The right to a basic education" 530. 
"opt in" class action, with approximately 80 schools "opting in" as applicants.

McConnachie and Breener note that the school infrastructure (and textbook) cases were accompanied by "an extensive mobilisation campaign". 56 This included community activism, You Tube videos, camping outside the High Court during hearings, engaging print media, and the organisation of mass marches. They ascribe the eventual adoption of the Norms and Standards for Public School Infrastructure which detail the requirements for water and sanitation, electricity, safe classrooms accommodating a maximum of 40 learners, and eventually, internet connectivity, libraries, laboratories and sports facilities, as illustrative of the combined power of social movements coupled with legal intervention. ${ }^{57}$ It is important to reflect that the Norms and Standards were released only after successful further litigation to compel the Minister to produce these. 58

The most recent judgments on the Norms and Standards bear noting: in Equal Education v Minister of Basic Education, AJ Mziza noted that the parties agreed that the right to education was of the "highest order" of socio economic rights. The application sought to declare unconstitutional those subparts of the Regulations that subjected the implementation of the Norms and Standards to available resources and to the co-operation from other government agencies and entities responsible for infrastructure in general, and their making available such infrastructure. ${ }^{59}$ The basis for this claim of unconstitutionality was that it gives Government a means of escaping the obligation to provide adequate school infrastructure due to the "clawback" provisions.

"As I understand the argument put forward by the Minister, her hands are tied. To me, this means that she is at the mercy of the other departments and organs of State. This simply compromises the constitutional value of accountability. There is no way that the Government can be held accountable for the discharge of its duty to provide basic basic school infrastructure. Therefore, because the provision of basic infrastructure is indisputably an integral component of the right to basic education, it means Government cannot be held to account ..."60

The prioritisation in the Norms of eliminating schools built "entirely" (rather than partly) of hazardous materials or which were unsafe was, moreover, found to be irrational: an unsafe structure poses the same risk to learners and teachers whether there are also some safe structures at the school. ${ }^{61}$ And school infrastructure already planned for could not be

56 McConnachie and Breener "Litigating the Right to Basic Education" 289 and 292.

57 McConnachie and Breener "Litigating the Right to Basic Education" 290.

58 Equal Education v Minister of Basic Education 20189 BCLR 1130 (ECB) par 14; See too Minister of Basic Education v Basic Education For All 20164 SA 63 (SCA).

59 Par 61.

60 Par 182. 
excluded from the Norms altogether on any rational basis, as they would then remain outside of the purview of the Norms indefinitely. The Minister's claim that she was hamstrung to allocate resources for infrastructure should have been justified in terms of the Constitution, which was not done. ${ }^{62}$ In what may be a high water mark in this particular litigation trajectory, the CC dismissed the Minister's application for leave to appeal - it bore no prospects of success.

Considering that children spend at least 9 years of their lives - half their childhood - in school, it is not unexpected that school governance has been a challenging arena, especially given the context of past discrimination and inequality in the school system. The powers of school governing bodies have been the subject of not inconsiderable contestation, and the distribution of power between parents, the executive, learners and educators has reached the CC on a number of occasions. ${ }^{63}$ School feeder zones, which entrench spatial inequality, and language policy have been core themes. Religion and schooling has also been a notable topic, not limited to the corporal punishment issue in the Christian schools case, or to apparel and insignia. ${ }^{64}$

\section{Some key features of 20 years of child rights jurisprudence in South Africa}

\section{Reach and scope}

My previous articles have highlighted the broad church of issues that have been brought to the attention of courts in which children's rights have surfaced. As was held in $S v M$ (Centre for Child Law as Amicus Curiae), the language of s 28 of the Constitution is "comprehensive and emphatic" and it has indeed come to pass that "statutes must be interpreted and the common law developed in a manner which favours protecting and advancing the interests of children". ${ }^{65}$ This has continued to occur, in fields as diverse as striking down provisions which enshrined

\footnotetext{
61 Par 192.

62 Par 195

63 McConnachie and Breener "Litigating the Right to Basic Education" 286-7. See in particular Head of Department, Department of Education, Free State Province v Welkom High School 20142 SA 228 CC, MEC for Education Gauteng Province and others v Rivonia Primary school and others 2013 ZACC 34, and Federation of Governing Bodies for South African Schools v MEC for Education, Gauteng and Another 2016 ZACC 14.

64 See Kruger and McConnachie "The impact of the Constitution on learners rights" in Boezaart (ed) Child Law in South Africa Juta, discussing inter alia Organisasie Vir Godsdienste-Onderrig en Demokrasie v Laerskool Randhart 20173 All SA 943 (GJ) in which it was ruled that it was "unlawful for a school to promote or allow its staff to promote that it, as a public school, adheres to only one or predominantly one religion to the exclusion of others."

65 Par 15.
} 
the prescription of sexual offences committed against children, ${ }^{66}$ upholding the genetic link requirement for confirmation of a valid surrogacy agreement on children's rights grounds (on behalf of yet-tobe-born children), ${ }^{67}$ and confirming the hopelessness of an appeal to overturn the schools Norms and Standards judgment. As has been noted, children's rights litigation has become socially accepted and legitimated - it is no longer necessary to first argue the virtues of children's rights, or claim them on a basis of good morals: their legal function is now "self executing". They demand accountability on the part of the state.

South African children's rights jurisprudence is consequently arguably the most far reaching currently in the world in having expanded the locus of its application far beyond the family law terrain. Indeed, this retrospective has for the most part eschewed discussing all the many family law cases that have been reported, in favour of focussing on those with a public law dimension.

\section{Judicial and litigator familiarity with children's rights}

In the 2008 article, an allusion was made to the specialised children's rights knowledge of some of the key judges, emanating from the predemocracy era. It was averred that they had (at times mero motu) flagged children's rights issues where these had not been argued by counsel. 20 years into democracy, I would argue that that conclusion continues to bear relevance, despite the fact that scores of newer judges now populate the bench. YG, penned by Judge Raylene Keightley, ${ }^{68}$ provides no better example; also, the judgment in the High Court of Judge Joseph Raulinga (formerly of the National Children's Rights Committee) in Media $24 \mathrm{v}$ National Prosecuting Authority ${ }^{69}$ concerning the expansive measures put in place (in a criminal trial of extreme public interest in which one accused was a minor) to balance open access to justice with the right to privacy of the child defendant is worthy of note. Furthermore, the case that ended as Director of Public Prosecutions, Transvaal $v$ Minister for Justice and Constitutional Development and Others ${ }^{70}$ emanated from Judge Eberhard Bertelsman's decision in the High Court when he raised constitutional questions pertaining to child victims and witnesses - he has long been an aficionado of the children's rights community. Ballast can also be sought in the fact that at least in the Gauteng divisions, judges alert children's rights litigators to cases where a child rights issue may be at stake, and invite them to enter as amicus. An example is in the string of surrogacy cases that have been litigated in these courts, ${ }^{71}$ the

66 Levenstein v Estate Late Sidney Frankel 2018 ZACC 16, although the case was won on behalf of all victims (adults as well).

$67 A B v$ Minister of Social Development 2017 BCLR 267 (CC).

68 Keightley Children Rights Juta was edited by her in 1996 in her position as a former academic.

6920112 SACR 321 (GNP)

7020092 SACR 130 (CC).

71 Sloth-Nielsen "Surrogacy in South Africa" in Scherpe, Fenton Glyn and Kaan (eds) Surrogacy around the World Cambridge University Press, 2019185. 
invitation to act in the swopped babies and customary adoption case, ${ }^{72}$ and indeed in YG itself.

Added to this is the fact that there is now a generation of litigators now schooled in and comfortable with 20 years of children's rights litigation, unafraid to raise these arguments when they may advance children's rights. This stands in quite stark contrast to the period after Grootboom in 2000, when some litigators feared that the CC's reference to children being "loved for who they are", and "not being stepping stones to resources”, weighed against using children's rights arguments, especially if women's rights claims stood a chance. ${ }^{73}$

\section{Protection and autonomy}

Recognition of children's evolving maturity warranting their need for protection and simultaneous awareness of their autonomy has been a key theme identified in the construction of the "constitutional child". This has been identified in relation to cases already mentioned, such as Centre for Child Law $v$ Minister of Justice (on life imprisonment as a sentence for children) ${ }^{74}$ and $S v M$ (Centre for Child Law as Amicus Curiae).

But the pendulum does sometimes swing between these policy values, illustrating that they embody as much tension as they do coherence. ${ }^{75}$ Two examples support this point.

It has been alleged that Teddy Bear Clinic is an extraordinary judgment, ${ }^{76}$ recognising as supreme children's right to privacy and to dignity, which triumph over conservative moral judgments enforced through the blunt instrument of criminal law.

72 Case no 32053/2014 Gauteng Division Pretoria. The cases concerned two children swapped at birth, and who were thereafter raised by families who were not biologically related to them. This was discovered only when paternity tests were performed as an adjunct to a later application for child maintenance when one ot the family's relationship ended,

73 See the mutedness of the children's rights argument in TAC $v$ Minister of Health and Others. The author was at the time attached to the Community Law Centre (now Dullah Omar Institute) prepared the amicus briefs for this case, and was appraised of the decision to avoid children's rights arguments in the papers (even though the subject, the availability of antiretrovirals to prevent mother to child transmission of HIV, concerned babies).

7420096 SA 632 (CC).

75 See the argument by Skelton ("Balancing autonomy and protection in children's rights: a South African account” 2016 Temple Law Review 887) as to why litigators opted not to use neuroscience research on the (delayed) development of adolescent brain in Teddy Bear Clinic, as overly protectionist. This position might have undermined the arguments privileging sexual autonomy and freedom of choice of those same adolescents.

76 Witting "Regulating bodies: the moral panic of child sexuality in the digital era" 2019 Critical Quarterly for Legislation and Law (forthcoming). 
The CC held that giving expression to our sexuality is at the core of the area of private intimacy: if in expressing our sexuality we act consensually and without harming one another, invasion of that space constitutes breach of privacy. ${ }^{77}$ This applies in equal force to consensual sexual conduct of adolescents (and this breach was exacerbated by the mandatory reporting requirements). Striking down as unconstitutional the offending criminal provisions which penalised consensual teenage sexual intimacy, the CC gave primacy to the autonomy side of the scale.

But protectionism has held sway in other cases. In Du Toit v Ntshinghila and others ${ }^{78}$ the need to protect the reasonable privacy interests of the children who are depicted in pornographic images, the significant public interest in ensuring that no duplication or distribution of images of child pornography occurs in the disclosure process, and the prevention of sexual exploitation of children, were all adduced to resist a claim that an accused be given copies of child pornography images prior to prosecution.

But Centre for Child Law v Media $24 \mathrm{Ltd}^{79}$ reveals further dimensions of the tension alluded to above. The case was portrayed in public as a victory for children's rights. ${ }^{80}$ To the extent that the cross appeal was partially successful, and the SCA declared that the provisions of S 154 (3) of the Criminal Procedure Act 51 of 1977 were constitutionally invalid to the extent that they did not protect the anonymity of child victims of crimes who did not testify at criminal proceedings, ${ }^{81}$ this is true. However, the greater portion of the judgment deals with what the bench called "the adult extension", namely whether the protection afforded children regarding disclosure of their identities whilst under 18 would extend into adulthood. According to the appellants, an interpretation that ensured ongoing protection, better promoted section 28(2) and protected child victims, witnesses, accused and offenders from the severe harm of identification. ${ }^{82}$ The respondents denied that there was any legal basis for the so-called "principle of ongoing protection".

The SCA was of the view that "[i]t is clear that the adult extension severely restricts the right of the media to impart information and infringes the open justice principle. In the absence of any legislation on

77 Teddy Bear Clinic par 59 and 60.

7820162 All SA 328 (SCA)

792018 ZASCA 140. At the time of writing, the case has been appealed to the Constitutional Court. Judgment is awaited.

80 By a spokesperson for the Centre for Child Law on national television.

81 The existing section afforded protection to child accused and child witnesses below the age of 18 years, but not to child victims who did not testify. The case was occasioned by a prior application to protect the identity of "Zoe Nurse", kidnapped as a 2 day old baby and rediscovered shortly before her 18th birthday by her biological parents. She did not testify at the criminal trial of the woman who raised her. Once she turned 18 , the media threatened to reveal her identity to the public in the sensational and tragic case.

82 Par 10. 
the nature and extent of the adult extension, the relief sought by the appellants is overbroad and does not strike an appropriate balance between the rights and interests involved." Accordingly, the proposed limitation asked for by the appellants on the right of the media to impart information was neither reasonable nor justifiable, in terms of s 36 of the Constitution. $^{83}$

In a minority judgment, the opposite was argued: that

"At first blush, it may seem that the difference between Swain JA and me is finely calibrated. Regrettably, we are separated by a philosophical ocean. In my opinion, when it comes to the disclosure of the identity of childhood victims of crime, logic, common sense and ordinary, everyday morality generate a constitutional imperative. It is that the relevant time, which is determinative of the issue, is the time that the person was a child and not the time from which the child has become an adult. In my opinion it is obvious that if, in balancing the competing interests at stake in this matter, the fulcrum is the question of onus, the scales must tilt in favour of those who have become adults but were the victims of crime at a time when they were children." 84

In a carefully crafted judgment, Willis JA for the minority held that "[a] default position in law that allows for a retrospective intrusion into a person's victimhood of crime as a child would, in my opinion, violate that person's constitutional right to dignity. The knowledge, as a child, that one's identity as a victim of crime may be revealed upon the attaining of one's majority, may haunt that child, causing her considerable emotional stress. In my opinion, it verges on cruelty to sanction torment such as this." 85

The minority therefore held that the preservation of the anonymity of the child should be the default position absent consent to reveal the identity subsequent to reaching the age of 18 years. This door is not yet closed, as the matter has been appealed to the CC, which has previously granted extended life-long protection to child victims' identities (in a case involving a claim for delictual damages). ${ }^{86}$

My assessment, therefore, does not discount that there may thus be deep differences regarding the substance and normative requirements of a child rights approach that will continue to prevail in some areas: substantiating this claim are the cases in which lengthy minority

\footnotetext{
83 Par 27.

84 Par 97.

85 Par 83.

86 "This is in the best interests of the child, not merely in light of the child's right to privacy, but because when the child 'becomes an adult the many physical disabilities suffered by the [child] will result in vulnerability. If the sums of money at the [child's] disposal as a result of this [judgment] are readily to be found out on the internet, there will be a risk of the [child] losing that money to inappropriate friends, fortune hunters or even thieves."” MEC, Health and Social Development, Gauteng v DZ 2017 ZACC 37 at fn 1 .
} 
judgments have been written. $C v$ Minister of Health and Welfare Gauteng, ${ }^{87}$ concerning whether the failure of the Children's Act to provide for an automatic judicial review of a removal of children effected without a warrant was constitutional, produced two substantial minority judgments; the SCA judgment in the Media 24 case is also emblematic of this, as the quoted excerpt shows. $A B v$ Minister of Social Development (concerning the genetic link requirement for surrogacy) gave birth to such a lengthy minority judgement that it could have been mistaken for a majority judgment: obviously, the differences touched a deep core amongst the Justices. Who can predict how YG and the common law defence of reasonable chastisement will fare in the CC?

The potential divergence between protection of children and giving effect to their autonomy is impossible to dissect or expand any further, in the absence of concrete and real life situations in which to situate such a debate. But in a cautionary vein, the lesson of Le Roux $v$ Dey $^{88}$ (holding schoolboys liable in delict for defamatory material circulated about their deputy headmaster) ${ }^{89}$ shows that, sometimes, recognising children as autonomous rights bearers can cause claimants to "fall on their sword". 90

\section{Innovative remedies}

A selection of the array of remedies that have been brought about in children's rights constitutional litigation has already been alluded to: striking down legislation, reading in, structural interdicts, intervention in procurement disputes to mitigate the impact on children's rights, ${ }^{91}$ and damages have all been the outcome of litigation. The litigation around schools provisioning has undoubtedly seen some of the most inventive remedies being devised. McConnachie and Breener ascribe this to the non-compliance of Departments with prior orders or settlements, prompting applicants to return to court to restructure relief. ${ }^{92}$ This even extended to taking measures to attach the motor vehicle of the Minister in order to satisfy the debt for teacher's salaries! And unprecedented was the relief to learners in Limpopo whose textbooks had not materialised, rendering them unable to cover the school curriculum effectively: the

872012 ZACC 1.

8820116 BCLR 577 (CC).

89 They superimposed the heads of their two teachers on the picture of two men depicted in a sexually suggestive position.

90 I make this claim even though the majority decision did not consider children's rights. Most discussions of the case privilege discussions of the minority judgments which do traverse children's rights: see Kruger and McConnachie "The impact of the Constitution on learners rights" 560-561 and Couzens "Le Roux $v$ Dey and a children's rights approach to judging" 2018 PER 1.

91 Proudlock "Children's socio-economic rights" in Boezaart (ed) Child Law in South Africa gives an overview of the relevant cases.

92 McConnachie and Breener 299. 
Department was ordered to draft and implement an extensive "catch up" plan to remedy the damage done. ${ }^{93}$

Whilst in South African jurisprudence, the terrain of child law is not alone in innovating remedies, the range of remedies and results cited by the authors reviewed does seem to set a rather high bar for other jurisdictions to follow.

\section{The spade work of "best interests" and "dignity"}

"Best interests" as a constitutional right, rule of procedure, and a principle have been fairly exhaustively analysed thus far. ${ }^{94}$ As Gallinetti has previously noted, ${ }^{95}$ the approach of the Court "underscores the need to mainstream the best interests principle in all legal arenas where children are involved even where established legal rules or principles have never given regard thereto previously". According to S $v M$ (Centre for Child Law as Amicus Curiae), best interests requires first, consideration of the interests of children; second, the retention in the inquiry of any competing interests; , third, the apportionment of appropriate weight to the interests of the child; ${ }^{96}$ and fourth, overall, the rights and interests of children must be considered independently of those of their primary care-giver. Section 28(2) mandates courts in particular to play a very active role in raising and securing children's best interests. ${ }^{97}$ Where parents or legal representatives do not defend children's best interests, courts must ex officio come forward to do so. The need for a best interest inquiry also presupposes that courts have sufficient information at their disposal to understand the impact of their decision upon children.

Inflexible policies ${ }^{98}$ may fall foul of section $28(2)$ because they do not cater to the individualised approach required. "Best interests" safeguards children's rights against arguments based purely on legal technicalities which do not take into account their individual circumstances. ${ }^{99}$ "Best interests" has been held to underpin the need for a remedy even where, technically, no violation or breach has been found, as in the requirement that the school review its policy on pregnant learners in the Welkom schools case. ${ }^{100}$ And the "nude" best interests principle contained in

93 McConnachie and Breener 300.

94 Bonthuys "The best interests of children in the South African Constitution" 2006 International Journal of Law, Policy and the Family 23.

95 Gallinetti "2kul2Btru: What children would say about the jurisprudence of Albie Sachs" 2010 SAPL 2010108 at 115.

96 Par 22, 26 and 32.

97 See too Van den Burgh discussed in South-Nielsen and Kruuse.

98 Head of Department, Department of Education, Free State Province v Welkom High School [2013] JOL 30547 (CC).

99 Sloth-Nielsen and Mezmur "Illicit Transfer by De Gree" 2007 Law, Democracy and Development 1.

100 Couzens "The South African Constitutional Court and the Best interests of the Child" in Diduck, Peleg and Reece (eds) Law in Society: Reflections on Children, Culture, Family and Society Brill 2015 534. At 535 she notes: "Thus section 28(2) justified the crafting of a remedy in somewhat unusual 
section 28(2) was used to fashion a solution to order de facto ${ }^{101}$ adoptions in the "baby swap" cases - even in a situation where adoption was not part of the common law (and could therefore not be developed), nor did the provisions of the Children's Act have any bearing because both babies (now children) were not orphaned or abandoned or in need of permanent alternative care, and were therefor ineligible for statutory adoption.

Finally, although the courts have repeatedly stated that "best interest" is not a trump over all rights, it remains a right which is accorded a degree of privilege in the balancing of rights. ${ }^{102}$

It can be concluded - as Couzens ${ }^{103}$ has done - that "best interests" is hardly an empty vessel any longer, into which the whims of the decision maker can be poured, with indeterminate outcomes, an uncertain reach and an unpredictable result. It has indeed served as a "multifunctional tool". ${ }^{104}$ That there is plenty of scope for further clarity on the normative content of this right in specific situations seems obvious: the next twenty years of children's rights constitutional litigation will tell.

Dignity has continued to form the bedrock of many judicial pronouncements on children. Thus in De Reuck, it was said that

“[c]hildren's dignity rights are of special importance. The degradation of children through child pornography is a serious harm which impairs their dignity and contributes to a culture which devalues their worth. Society has recognised that childhood is a special stage in life which is to be both treasured and guarded."105

And in YG, Judge Keightley reiterated that " $[\mathrm{u}]$ nder the Constitution the child enjoys the general right to dignity under section 10. In addition, children enjoy special protection under section 28(1)(d) to be protected from, among other things, degradation. Human dignity lies at the heart of this latter protection. In turn, the right to dignity is foundational to our

circumstances, when a human rights violation has not been fully established. Such a drastic remedy was nonetheless necessary because of the serious impact of children of the school policies. The remedy was envisaged to have a pre-emptive effect- rather than an ex post facto remedial impact."

101 Case no 32053/2014 Gauteng Division Pretoria. See further note 74 above.

102 Couzens note 102538.

103 Couzens note 102 538. "Section 28(2) has been used by the Court to create obligations which make the law more responsive to children's needs as rights holders .... It is perhaps symbolic that the Court rather than grounding this jurisprudence in the right to equal protection of the law (section 9(1) of the Constitution) or the right to an appropriate remedy (section 38 of the Constitution), the Court often relied on section 28(2). It seems that for the Court this section is quintessential for giving children the legal protection which is due to them."

104 Couzens note 102545.

105 Par 63. 
constitutional dispensation." 106 Noting that dignity plays a twofold role in the consideration of the constitutionality of the defence of reasonable chastisement, ${ }^{107}$ she explains that whereas adults who are victims of assault enjoy the protection of the law to vindicate their rights, the child, by virtue of the potential of the reasonable chastisement defence to block such vindication, is "treated with a lesser level of concern" 108 and the state is given less power to protect his or her rights. The effect is to deny the child's independent right to dignity and to subsume his or her dignity interests under that of his or her parents - in direct contrast to $S v M .^{109}$

In 2013, Kruuse and I wrote of dignity as follows:

"we contend that the elaboration of a children's right to dignity holds considerable promise as a tool for future legal interpretation. In our view, it provides a more concrete and authoritative (sophisticated) basis for adjudicating the complex interplay of competing rights where children are concerned by comparison to the more simplistic and a-contextual so-called 'balancing' of rights that courts allude to practicing."

Has this promise been true? At this stage, I do not believe that many noteworthy advances have been made in support of that contention. Dignity, generally, has surfaced rather tangentially, for instance in relation to core principles of privacy and autonomy in the Teddy Bear Clinic case, rather than as a standalone embodiment of children's rights as human beings. Its contours, how it can assist to resolve tensions between competing interests, and to which fields of inquiry children's dignity must be brought in, remain rather opaque. Therefore, unless the CC develops a more focussed understanding of children's dignity (within a rights based approach) - as it may well yet do in YG - dignity remains rather subordinate to "best interests" as a tool for developing our conception of constitutional children's rights.

\section{Engagement with international law}

Quite a few commentators have previously embarked on the study of the court's use of international and regional law in bolstering its jurisprudence. ${ }^{111}$ Meda Couzens' as yet unpublished work is particularly interesting; it seeks to describe how the CC and the SCA have engaged

106 Par 71

107 The first is in the breach inherent in the breach of the child's right to physical integrity.

108 Par 72.

109 Par 74.

110 Sloth-Nielsen and Kruuse 669.

111 See my own publications of 2008 and 2013, as well as Skelton "The development of a fledgling child rights jurisprudence in Eastern and Southern Africa based on international and regional instruments" 2009 AHRLJ 482; Ngidi “'The role of international law in the development of children's rights in South Africa: A children's rights litigator's perspective' in Killander (ed) International law and domestic human rights litigation in Africa (PULP, 2010) 173; Skelton "Child Justice in South Africa: Application of International Instruments in the Constitutional Court” 2018 IJCR 391. 
with the Convention on the Rights of the Child (CRC), in an attempt to uncover its "jurisprudential value added" (alongside the provisions of section 28 of the Constitution itself). She notes that as at December 2017 , there had been 16 cases in each of these courts in which the CRC was referred to or relied upon. She suggests that

"The courts have been receptive to the $\mathrm{CRC}$, a receptiveness which extends to soft-law instruments, such as general comments of the CRC and other UN documents. While the courts do not always give close attention to the standards of the CRC or sometimes plainly ignore it, apart from Jafta J's rejection of the CRC in C v Department of Health on grounds that it was not incorporated domestically, the legitimacy of references to the CRC has not been contested. As a consequence, there is little judicial preoccupation with the domestic legal status of the CRC. Whether this indicates an unconditional embracing of the CRC is a matter of some uncertainty, as the CRC has generally been invoked to obtain outcomes also supported by the Constitution, and the state has not opposed its application by courts." 112

She affirms that "the use of the CRC as a reference framework can be found in those cases where courts make statements as to the compatibility between domestic standards and the CRC"113 which strengthen the weight and legitimacy of the constitutional norm at stake. There are also cases she discusses (some of which I have discussed in this article) in which reliance is placed on the CRC as a guide to judicial discretion. This involves courts using the CRC as an aid in making a choice between legitimate solutions, with children's rights weighing in the balancing act.

She also refers to the "less tangible influences" of the CRC (seen in combination with the Constitution), including by "changing hearts and minds over time". ${ }^{114}$ She opines that these strengthen the legitimacy of the $\mathrm{CRC}$ as a habitual presence in the judicial discourse. These remarks apply, with the changes required by the context, to constitutional children's rights.

\section{Conclusion}

It is tempting to be rather self-congratulatory about the ongoing constitutional enterprise to advance children's rights. This reflective overview indicates that the past twenty years have yielded a rich and remarkably interesting array of cases - and that more are yet to come. Although I do not believe that I have raised any particularly new or surprising insights that have not already been said before, final comments on the significance of the constitutional children's rights journey are apposite.

112 Couzens "The application of the United Nations Convention on the Rights of the Child by national courts" LLD thesis University of Leiden, 2019175.

113 Couzens 179.

114 Quoting Sloth-Nielsen 2001. 
First, constitutionalising children's rights has the advantage of elevating their status to the highest point in a legal system. This brings the twin advantages of entrenchment (making them harder to erode) and supremacy (making it possible to enforce children's rights in the face of conflicting lower laws and policies). ${ }^{115}$ As O'Mahony noted, ${ }^{116}$ this effect can be magnified when the best interests principle is constitutionalised and can ensure that court cases are framed in a child-centred manner rather than be dominated by the constitutional rights of adults.

Second, Federle speaks of rights having the capacity to shift the balance of power. ${ }^{117}$

"An understanding of power is central to any effort to reconstruct rights for children ... Because of the nature and fluidity of power, it structures and shapes our personal interactions and relationships in ways that permit us to assert dominance or engage in submissiveness. But political, legal and social frameworks limit the ways in which individuals may negotiate for or assert power; whilst such limitations provide some certainty and stability in our interactions, they also create opportunities for the accretion of power and the subordination of other interests .... . Rights claims command the respect of others in our society and demand that one be taken seriously, whilst recognising the claimant's independent value as a human being. For children, rights talk does have a place in their lives by offering an alternative approach to paternalistic practices." 118

This, I believe, is the central lesson that 20 years of constitutional children's rights litigation has taught: that the paternalism so characteristic of the welfarist approaches that used to occupy centre stage in the law's construction of children has been pushed aside in the face of the swell of constitutionalism.

115 O'Mahony 3.

116 O'Mahony 4.

117 Federle “Do Rights Still Flow Downhill?” 2017 IJCR 273.

118 Federle 281-2. 